\title{
COMPARATIVE STUDY OF THE BIOLOGICAL BEHAVIOUR IN HAMSTER OF TWO ISOLATES OF LEISHMANIA CHARACTERIZED RESPECTIVELY AS L. major-like AND L. donovani.
}

\author{
M. I. S. DUARTE (1), M. D. LAURENTI (1), H. F. ANDRADE JR. (1, 2) \& C. E. P. CORBETT (1)
}

\author{
S U $\quad \mathbf{M} \quad \mathbf{M}$ A $\mathbf{R} \quad \mathbf{Y}$
}

Hamster inoculated intraperitoneally with $1 \times 10^{7}$ parasites of L. donovani and L. major-like of the New World were studied in groups of 15, 30, 60 and 90 days of infection. The parasite load and density showed progressive increase with the evolution of the infection and was higher in the L. donovani groups than in the L. major-like groups. The $\mathbf{L}$. major-like groups showed parasite density higher in the spleen than in the liver and was similar in both organs in L. donovani groups. The histopathology showed a diffuse marked hyperplasia and hypertrophy of the reticuloendothelial system with high parasitism in the $\mathbf{L}_{\mathbf{+}}$ donovani groups while there was focal involvement of these organs in L. major-like groups, forming nodules of macrophages that were scantly parasitised.

The biological behaviour could be useful in the preliminary studies of Leishmania strain in regional laboratories and understanding the histopathology of lesions caused by different leishmania species.

KEY WORDS: Leishmania; L. donovani; L. major-like; Experimental infection.

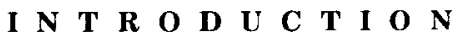

The leishmanias are intracellular parasites whose tissue tropism vary from species to species. The infection caused by $\mathbf{L}$. donovani shows visceral involvement with predilection for organs rich in reticuloendothelial tissue such as spleen, liver and bone marrow (ADLER, 1963; BRAY, 1974; BRADLEY \& KIRKLEY, 1977 and MELENEY, 1925). The cutaneous leishmaniasis, such as those caused by the $L$. tropica and $\mathbf{L}$. major in the Old World and L. brasiliensis and L. mexicana in the New World, show a parasite preference for skin in spite of the detection of cryptic infections in other organs of experimen- tal animals (COUTINHO \& COELHO, 1972; SCHNUR, ZUCKERMAN \& MONTILO, 1973).

Previous studies on $\mathbf{L}$. donovani in hamsters showed an inverse correlation between the mean lifetime and the number of parasites in the inoculum and a direct correlation with the final parasitism of the spleen and liver (STAUBER, 1958). The inoculation route is also important in the development of the disease (BRADLEY \& KIRKLEY, 1977; OTT, HANSON \& STAUBER, 1967 and STAUBER, 1958). The differentiation of species of leishmanias using biological beha-

(1) Departamento de Patologia da Faculdade de Medicina da Universidade de São Paulo. (2) Instituto de Medicina Tropical de Sāo Paulo - Laboratório de Protozoologia.

Address for correspondence: Dra. Maria Irma Seixas Duarte. Faculdade de Medicina da Universidade de Sáo Paulo, Departamento de Patologia - Av. Dr. Arnaldo, 455 - 1: andar - sala 26 - CEP 01246 São Paulo, SP, Brasil. 
DUARTE. M. I. S: LAURENTI. M. D.; ANDRADE Jr. H. F \& CORBETT. C. E. P. Comparative study of the biological behaviour in hamster of two isolates of Leishmania characterized respectively as $\mathbf{L}$. major-like and L. donovani. Rev. Inst. Med. trop. São Paulo, 30 (1): 21-27, 1988

viour in hamsters has revealed many problems We do not know of any quantitative studies com paring visceral involvement of different species. but we think, that this colld be useful for initial studies using the analysis of the biological beha viour of new isolates for differention of the lesh mania species.

The histopathological study of experimen tal visceral leishmaniasis has been carried out by many authors (GELLHORN, et al. 1946; GU TIERREZ, MAKSEN \& REINER, 1984: MELE: NEY. 1925: RITTERSON, 1955: ZUCKERMAN \& LAINSON. 1977). We have been studying the histopathology of various organs from experi mental visceral leishmaniasis in hamster and ha ve previously described the visceral changes which occur (DUARTE \& CORBERTT, 1984 DUARTE, SESSO \& BRITO. 1978).

In our laboratory working with a strain of Leishmania, isolated frorn the liver of a dog from an endemic area of human visceral leishmania sis, we found, in hamster, parasite proliferation in liver and spleen with no evident involvement. of the skin. This strain was earlier characterized as $L$. donovani but a new identification using biochemical and immunological methods IMO MEN et al., 1984: PACHECO, 1985 and SHAW. 1985 - personal communication ) established as being a $L$. major-like. However, the visceral involvement was much more benign than that found in visceral leishmaniasis caused by a well characterized strain of $L$. donovani chagasi.

In this work we have carried out a compa rative study of the parasitism and the histopa thology of the spleen and liver of infected hams ters looking for a possible differentiation bet ween the L. donovani and L. major-like isolated in the New World.

\section{MATERIAI, AND METHODS}

Animals: male, outbread, hamsters, age 45-60 days old, from the University of Sào Paulo Medical School General Colony and kept in our laboratory were used IVAN JOOST \& SLUTERS. 1972).

Parasites: L. donovani (MHOM/BR/72/LD 46) was isolated by Dr. W. Mayrink. Federal Uni- versity of Minas Gelais. Brazil in October, 1972. from an human case of visceral leishmaniasis comming from Mantena (MG). The parasite was isolated using bone manuw aspirate and inocu lated into hamsters. We have maintained this parasite by inoculation every three months. It was characterized at the Wellcurne Parasitology Unit. Instituto Evandro Chagas, Belem, PA. using monoclonal antibodies and by isoenzyme methods in 1985 'SHAW -... personal commu nication

L. major like (MCAN BR 73 L.D 70 ) isolated by Dr. Magno Dias, Federal University of Minas Gerais, from liver of a dog from Conselheiro Pena (MG) in 1973. It was maintained in the laboratory by sub-inoculations every three months (PA CHECO, 1985: SHAW, 1985 - personal communication

Eight experimental groups of hamsters in fected with either L. donovani or with L. major like with at least four survining animals. Each animal was inoculated intraperitoneally with 1 $x 10^{7}$ amastigotes, determined by the stauber method (STAUBER, 1958) at intervals of 15,30 , 60 and 90 days after inoculation. Fragments from the liver and spleen were processed for light $\mathrm{mi}$ croscopy and for parasite load determination. Fragments from spleen ard liver were fixed in buffered $10 \%$ formalin solution ( $\mathrm{pH} 7.2$ ) and processed by usual histopathological techniques and stained with haematoxylin eosin.

The spleen and liver smears were fixed in methanol and stained by Giemsa's method. The parasite load of the spleen and liver were calcu. late by determining the number of amastigotes found per 1000 nuclei of the organs cells $\mathrm{x} 2 \mathrm{x}$ $10^{5}$ (STAUBER, 1958). The parasite density was obtained by dividing the parasite load of the or gar by its weight in milligrams iSTAUBER. 1958. Statistical analysis was performed using Students " $t$ " test, with 0,05 significance levels.

\section{RESUI,TS}

The distribution of the spleen and liver para site load can be seen in table 1 . There was a progressive increase of parasite in both species. The increase was bigger in animals infected with L. donovani than in those inoculated with $\mathbf{L}$. 
DUARTE, M. I. S.; LAURENTI, M. D.; ANDRADE Jr., H. F. \& CORBETT, C. E. P. - Comparative study of the biological behaviour in hamster of two isolates of Leishmania characterized respectively as L. major-like and L. donovani. Rev. Inst. Med. trop. Sāo Paulo, 30 (1): 21 -27, 1988.

TABLE 1

Parasite load and density of $\mathbf{L}$. donovani and $\mathbf{L}$. major-like in the spleen and liver of hamster

\begin{tabular}{|c|c|c|c|c|c|c|c|c|c|}
\hline \multirow[b]{2}{*}{$\begin{array}{l}\text { Experi- } \\
\text { mental } \\
\text { group }\end{array}$} & \multirow[b]{2}{*}{$\begin{array}{c}\text { Number } \\
\text { of } \\
\text { animals }\end{array}$} & \multirow[b]{2}{*}{$\begin{array}{l}\text { Time of } \\
\text { infection } \\
\text { (days) }\end{array}$} & \multirow[b]{2}{*}{ Strain } & \multicolumn{3}{|c|}{ Spleen } & \multicolumn{3}{|c|}{ Liver } \\
\hline & & & & $\begin{array}{l}\text { Weight (mg) } \\
\pm \text { standard } \\
\text { error (S.E.) }\end{array}$ & $\begin{array}{c}\text { Parasite } \\
\text { load } \\
\left(10^{6}\right) \pm \text { S.E. }\end{array}$ & $\begin{array}{c}\text { Parasite } \\
\text { density \& } \\
\left(10^{3}\right) \pm \text { S.E. }\end{array}$ & $\begin{array}{c}\text { Weight } \\
\text { (mg) } \\
\pm \text { S.E. }\end{array}$ & $\begin{array}{c}\text { Parasite } \\
\text { load } \\
\left(10^{6}\right) \pm \text { S.E. }\end{array}$ & $\begin{array}{c}\text { Parasite } \\
\text { density } \\
\left(10^{3}\right) \pm \text { S.E. }\end{array}$ \\
\hline I & 9 & 15 & L. donovani & $\begin{array}{l}143.33= \\
\{31.89\}\end{array}$ & $\begin{array}{l}2.39 \pm \\
11.591\end{array}$ & $\begin{array}{r}10.60= \\
5.03 ?\end{array}$ & $\begin{array}{c}4413.33= \\
1387.6 \%\end{array}$ & $\begin{array}{l}54.63 \pm \\
124.24\rfloor\end{array}$ & $\begin{array}{c}12.73= \\
15.921\end{array}$ \\
\hline II & 10 & 30 & L. donovani & $\begin{array}{c}244.00= \\
120.231\end{array}$ & $\begin{array}{r}13.02 \pm \\
14.141\end{array}$ & $\begin{array}{l}46.60 \pm \\
12.95 i\end{array}$ & $\begin{array}{c}4118.00= \\
|205.54|\end{array}$ & $\begin{array}{r}177.66 \pm \\
166.671\end{array}$ & $\begin{array}{l}47.99= \\
16.901\end{array}$ \\
\hline III & 6 & 60 & L. donovani & $\begin{array}{c}366.67= \\
137.211\end{array}$ & $\begin{array}{l}496.66 \pm \\
1150.501\end{array}$ & $\begin{array}{c}1422.91 \pm \\
1521.001\end{array}$ & $\begin{array}{c}5175.00 \pm \\
1198.42\end{array}$ & $\begin{array}{l}4383.00 \pm \\
11198.171\end{array}$ & $\begin{array}{l}842,60 \pm \\
226.00 \dagger\end{array}$ \\
\hline IV & $4^{*}$ & 90 & L. donovani & $\begin{array}{l}530,00 \pm \\
(82,86)\end{array}$ & $\begin{array}{l}700,70 \pm \\
(438.46)\end{array}$ & $\begin{array}{r}2017,00 \pm \\
11541.00\end{array}$ & $\begin{array}{r}4757,00= \\
1650.00\end{array}$ & $\begin{array}{l}1897,47= \\
11260,701\end{array}$ & $\begin{array}{l}498,00 \pm \\
1373,00 !\end{array}$ \\
\hline v & 6 & 15 & L. major-like & $\begin{array}{r}253,33 \pm \\
(92,00)\end{array}$ & $\begin{array}{l}0.42 \pm \\
10.111\end{array}$ & $\begin{array}{l}2.10 \pm \\
10.601\end{array}$ & $\begin{array}{c}3783.00 \pm \\
1152.00\end{array}$ & $\begin{array}{l}8.43 \pm \\
12.76\}\end{array}$ & $\begin{array}{l}2,21 \pm \\
10.751\end{array}$ \\
\hline VI & 7 & 30 & L. major-like & $\begin{array}{r}324,33 \pm \\
\{31,00\}\end{array}$ & $\begin{array}{l}1,73 \pm \\
10.691\end{array}$ & $\begin{array}{l}6.10= \\
12.67 \mid\end{array}$ & $\begin{array}{r}5184.00 \pm \\
|213.00|\end{array}$ & $\begin{array}{r}10.58 \pm \\
13.001\end{array}$ & $\begin{array}{l}2.14 \pm \\
10.64 t\end{array}$ \\
\hline VII & 5 & 60 & L. major-like & $\begin{array}{c}220.00= \\
(20.98)\end{array}$ & $\begin{array}{l}3.97 \pm \\
11.51)\end{array}$ & $\begin{array}{r}(8.90 \pm \\
(8.37)\end{array}$ & $\begin{array}{c}3606,00 \pm \\
1477,05\end{array}$ & $\begin{array}{l}22,48= \\
113,05\}\end{array}$ & $\begin{array}{l}7.75 \pm \\
15.601\end{array}$ \\
\hline VIII & 5 & 90 & L. major.jike & $\begin{array}{r}284,00 \pm \\
(15,03)\end{array}$ & $\begin{array}{l}9.90 \pm \\
15.34\}\end{array}$ & $\begin{array}{l}37.20= \\
221.80)\end{array}$ & $\begin{array}{c}4578,00 \pm \\
1156.76\end{array}$ & $\begin{array}{l}57.40 \pm \\
(30.66)\end{array}$ & $\begin{array}{c}16.70 \pm \\
|6.69|\end{array}$ \\
\hline
\end{tabular}

* 6 died before the $90^{\text {th }}$ day. $-\$$ Number of amastigotes per 1000 nuclei of tissue cells $\times 2 \times 10^{5}$ \& Number of amastigotes per milligram of the organ.

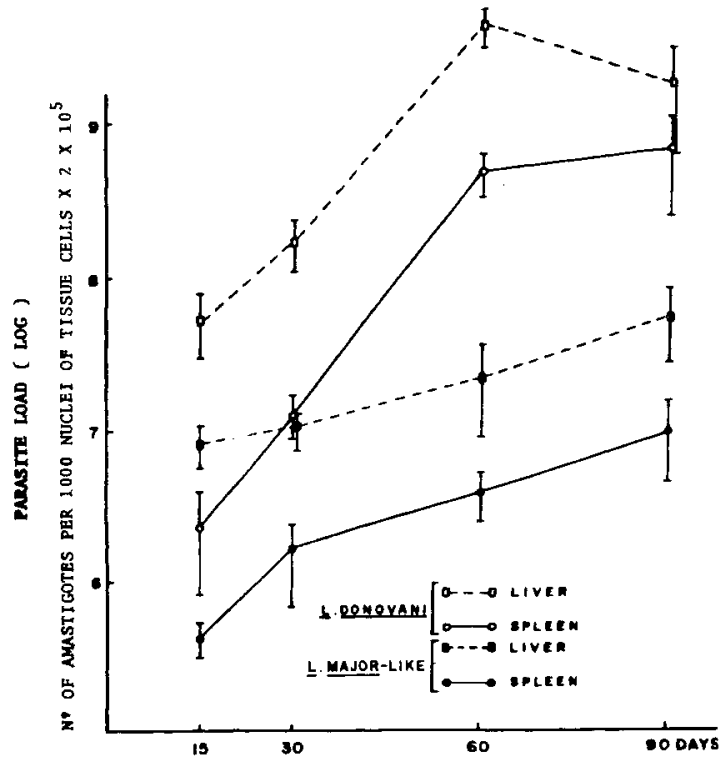

Fig. 1 - Evolution of the parasite load in liver and spleen of hamster inoculated with L. donovani and L. major-like. major-like and the difference was significant $(\mathrm{p}$ $<0,05$ ) from the $15^{\text {th }}$ day of infection onwards (Fig. 1).

The parasite density, i. e., the number of parasites per milligram of the organ (Fig. 2) showed clear differences in the behaviour of these two strains.

The L. donovani groups showed a faster pro liferation of parasites than the $\mathbf{L}$. major-like groups $(\mathrm{p}<0,05)$. The parasite density in the spleen and liver in all L. donovani groups was similar. Nevertheless in the L. major-like group this density was significantly higher in the spleen than in the liver with $\mathrm{a}$ ( $\mathrm{p}<0.10$ and $\mathrm{p}$ $>0.05$, respectively). The 90 day $L$. donovani group had only 4 animals because the other 6 had died before this time. These animals showed high parasitism of the spleen and liver and mar ked typical histopathological lesions of the disease. 


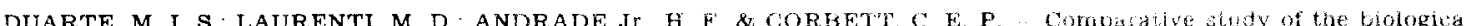

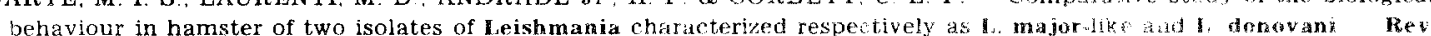
Inst. Med. trop. São Paulo, 30 (1):21.27. 1988

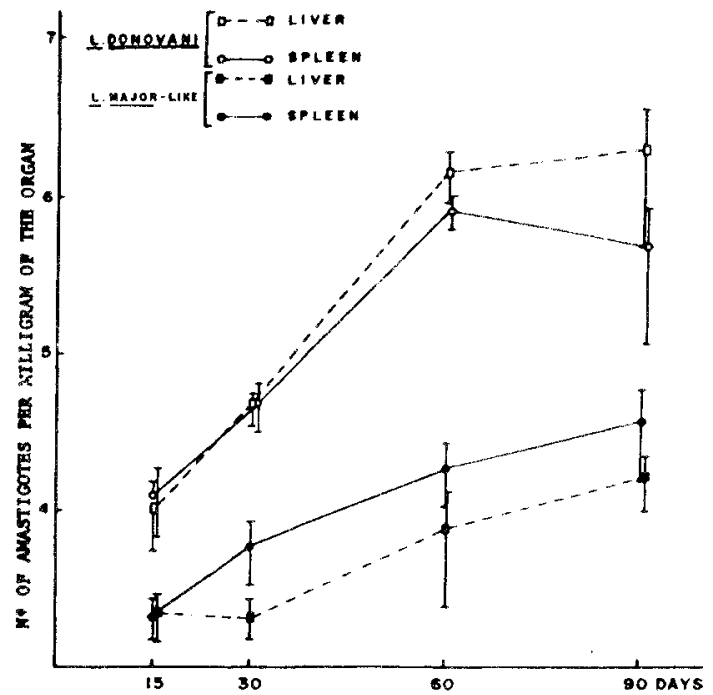

Fif, 2 -- Evolution of the parasite density in liver and spleon of hamsters inoculated with $\mathbf{L}$. donovani and $\mathbf{L}$. major like.

The histopathological analysis of the lesions in all groups gradually increased with time and a difference between the $\mathbf{L}$. donovani and $\mathbf{L}$. major-like involvement was noticed. In spite of all groups showing histopathological lesions in creasing with the time there was a different pat tern of involvement in the L. donovani group and in $\mathbf{L}$. major-like group. The changes were more diffuse in the $\mathbf{L}$. donovani group and nodu lar in the L. major-like group. In each parasite species group the type of histopathological in volvement was similar varying only in intensity with the time of infection.

The spleen and liver reticuloendothelial sys tem was highly parasitized from the begining in $\mathbf{L}$. donovani infected animals. The early liver changes (15 days infection) were moderate diffu se hyperplasia and hypertrophy of the Küpffer cells with discreet parasitism. Intralobular aggre gates of the phagocytic cells with high parasi tism were irregulary distributed within the hepatic lobules, with no preference for any particular zone. The portal spaces showed mild infiltration by lymphocytes, plasma cells and macrophages, some of them containing leishmanias. After 30 days of infection there was an increase in the hypertrophy and hyperplasia of the Küpffer cells and also higher parasitism. At the same time there was a deverst of lhe mbalobulat macro phage aggregates and portal monmuclear cells

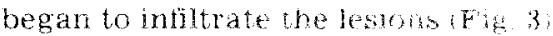

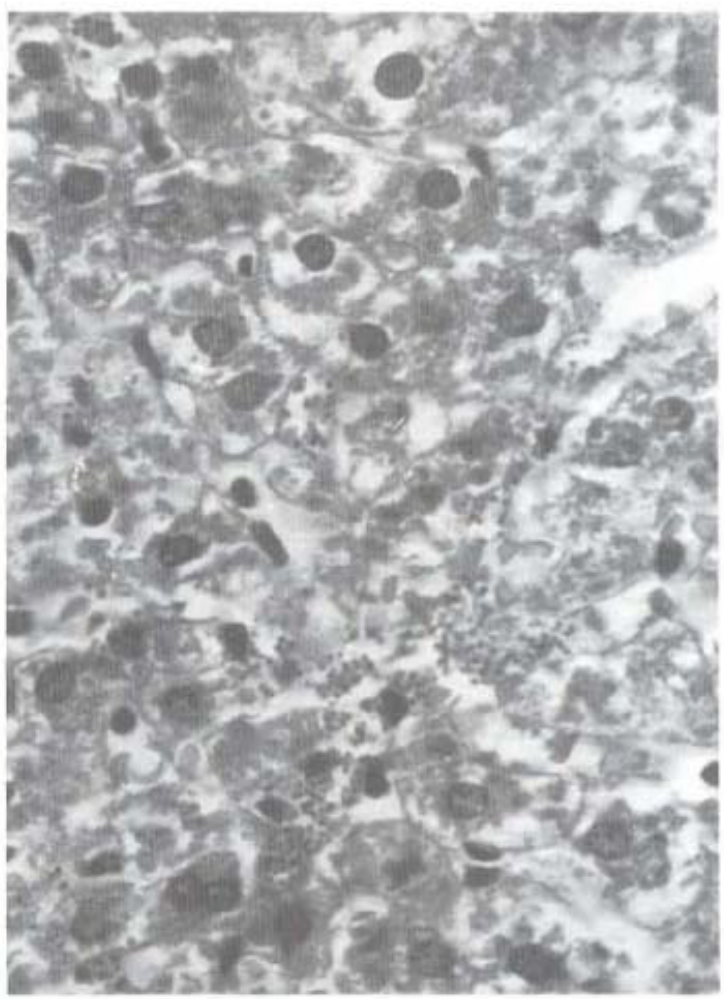

Fig. 3 - Liver from L. donovani group 60 days after infection: diffuse hypertrophy and hyperplasia of the Küpffer cells with severe parasitism ( $\mathrm{x} 506,9$ ).

The parasite density in the liver was lower with $\mathbf{L}$. major-like than with $\mathbf{L}$. donovani. The histopathology of the L. major-like group sho. wed multi focal lesions with no diffuse reticu loendothelial system hyperplasia as seen in $\mathbf{L}$. donovani group. The most frequent histopatho logical changes found were infralubular inflam matory nodules scattered throughout the paren chyma. These nodules were made up of macro phages together with lymphocytes forming small aggregates where the leishmanias were ei ther few or absent. There was also mild hyperplasia of the Küpfer cells which did not show any parasitism. The portal spaces presented dis creet infiltration by lymphocyles and macropha ges up to 30 days of infection groups and mode rate in the others two which showed also an in crease of plasma cells ( $\mathrm{Fig}$. 4 ). 


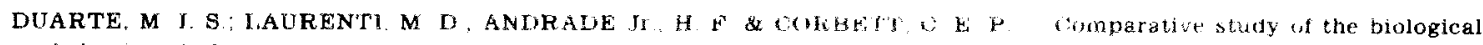

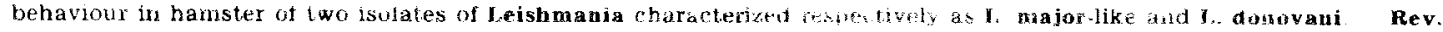
Inst. Med, trop. Sáo Fủ̧o, 30 (1): $212 \%, 1988$

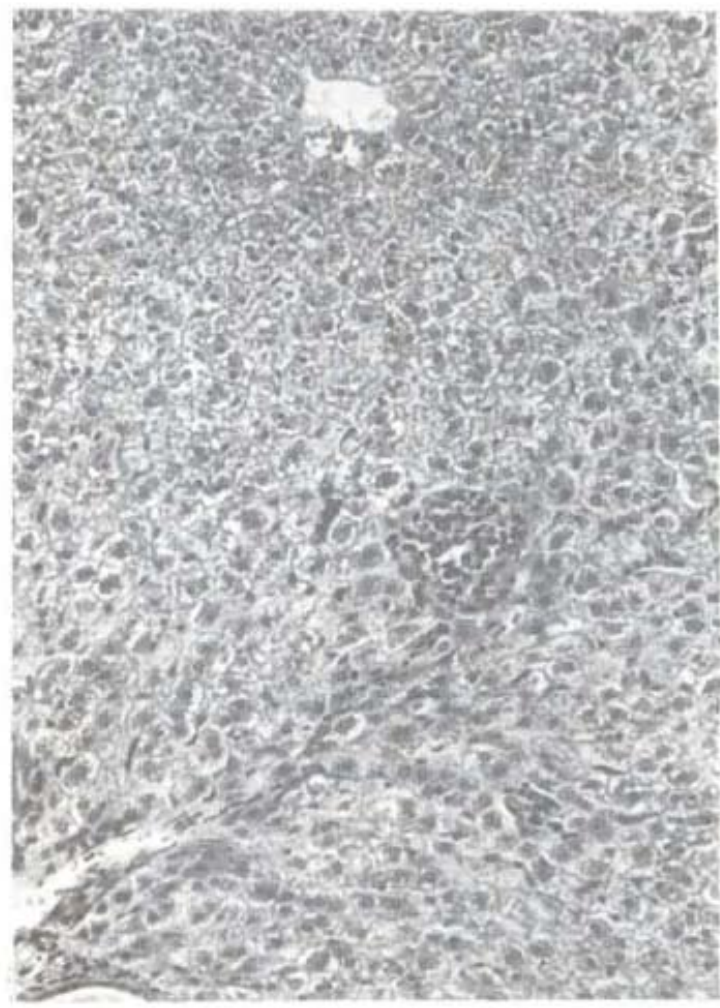

Fig. 4-Liver from L. major-like group 60 days after infection: intralobular nodules of macrophages, lymphocytes and plasma cells. There was scanty parasitism. (x 126,7).

In the spleen the most prominent changes found in the $h$, donovani groups were diffuse hyperplasia and hypertrophy of the reticuloen dothelial system within the sinusoids increasing in intensity in the other groups accompanied by marked parasitism (Fig. 5). On the other hand the L. major-like groups showed mainly nodules made up of macrophages with either mild or no derate parasitism scattered in the red pulp of the spleen (Fig. 6). In the oldest group there was also mild diffuse hyperplasia of the reticuloendo thelial systern. The lymphoid follicles of the whi te pulp moderately increased in volume with hy perplasia and parasitism of the macrophagic cells in the $\mathbf{L}$. donovani group. In the $\mathbf{L}$. major like groups there were discreet increase in the germinative centers with mild hyperplasia of the macrophages and occasional parasites were seen. The T-lymphocytes density in the lym phoid follicles was decreased only in the 9 ) days old L. donovani groups

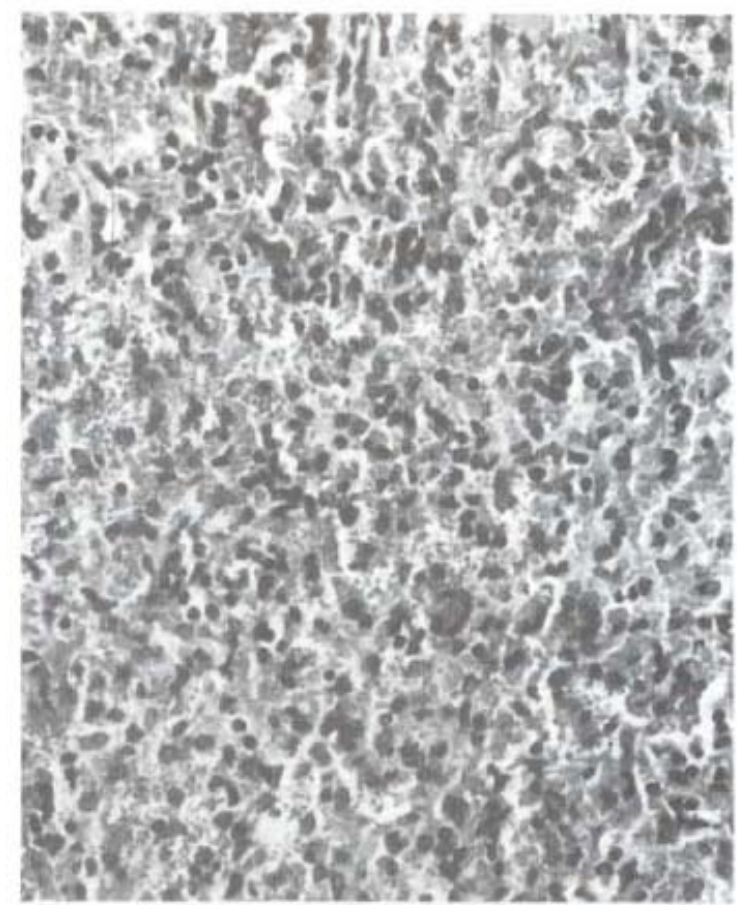

Fig. 5 - Spleen from L. donovani group 60 days after infection: diffuse hypertrophy and hyperplasia of the reticuloendothelial system with high parasitism. (x 253,4).

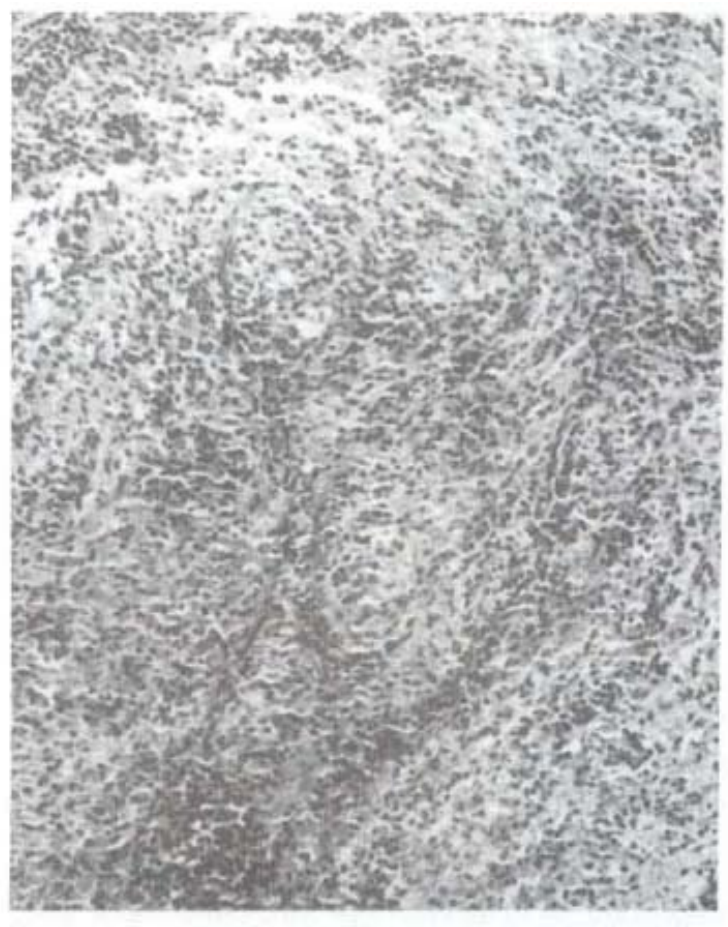

Fig. 6-8pleen from L. major-like group 60 days after infection: hypertrophy and hyperplasia of the mononuclear phagocitic cells arranged in nodules with rare parasites. ( $x$ 126,7). 
DUARTE, M. I. S.: LAURENTI, M. D.; ANDRADE Jr., H. F. \& CORBETT, C. E. P. - Comparative study of the biological behaviour in hamster of two isolates of Leishmania characterized respectively as L. major-like and L. donovani. Rev. Inst. Med. trop. São Paulo, 30 (1): 21 27, 1988

There was no change in the lymphocyte den sity either in the $\mathrm{B}$ or $\mathrm{T}$ dependent zone, in any the L. major-like groups.

\section{DISCUSSION}

The L. donovani group presented a parasite load and density higher than the L. major-like group in spleen and liver. However, the L. major like group showed higher concentration in the spleen than in the liver while the L. donovani groups showed no difference in these organs. The histopathology also showed significant differen ces between there two groups. The L. donovani groups had a more diffuse involvement with se vere reactivity of the reticuloendothelial system and high parasitism. The L. major-like groups showed focal involvement with intralobular ma crophages nodules scaterred, throughout the or gans, with few or no leishmania found into these nodules. There was low reactivity of the reticu loendothelial system where no parasite was seen. These differences seem to be determined by the two species studied (HOMMEL, 1978 ; MAUEL \& BEHIN, 1982). Even with the out standing taxonomic problems related to the leishmanias species of the New World (GARDE NER, 1977: HOMMEL, 1978) it is accepted that the L. donovani has a tropism for the viscera (ADLER, 1963; BRAY, 1974; BRADLEY \& KIRKLEY, 1977) and the L. major like for the skin (BRAY, 1974; ZUCKERMAN \& LAINSON 1977). Using biochemical methods and monoclo nal antibodies (MOMEN et al., 1984; PACHECO 1985; SHAW, 1985 - personal communication? this strains of a neotropical leishmania have re cently been identified as L. major-like. However, the strain used in the present studied is different from the $\mathbf{L}$. major, reference strain, in relation to the KDNA restriction enzymes analysis (MO MEN et al., 1985: PACHECO, 1985 I.

Strain MCAN/BR/73/LD70 was originally, isolated from dog liver and has not showed cuta neous tropism when inoculated intraperitonea lly in hamsters.

Others strains in the New World have been identified as L. major-like but there have been considered in some cases as result of laboratory "mix-ups" (SHAW, personal communication).
The exact nature of $\mathbf{L}$. major-like strains from Brazil must be investigated in greater detail. Epidemiological studies and identifications of new isolates must now be performed.

In conclusion we feel that it is very important to investigate the biological behaviour of new isolates for initial studies of different leishmania species which together with clinical and epidemiological observations will be useful for the understanding of the pathological changes causes by each species. Both studied species showed significant biological behaviour differen ces between them indicating that, such differen ces can be detectedusing quantitative and histo pathological methods.

\section{ACKNOWLEDGEMENTS}

This work was supported by FINEP 43/86/0361/00

We thank Maria Lúcia G. B. Barits for the technical assistance

\section{RESUMO}

Estudo comparativo do comportamento biológico de dois isolados de Leishmania caracterizados respectivamente como $\mathrm{L}$. major-like e $\mathrm{L}$. donovani, em hamster.

Experimentos utilizando-se hamsters inoculados intraperitonealmente com $1 \times 10^{7}$ parasitas de 2 cepas, L. donovani (MHOM/BR/72/LD 46) e L. major-like (MCAN/BR/73/LD 70) isoladas no Novo Mundo foram realizados e estudados em grupos de 15, 30, 60 e 90 dias de infecçāo. A carga e a densidade parasitária mostraram progressivo aumento com a evolução da infecçāo e foi maior nos grupos inoculados com L. donovani do que nos grupos inoculados com L. major-like. Os grupos inoculados com L. major-like mostraram densidade parasitária maior no baço que no figado e foram semelhantes em ambos os orgâos nos grupos inoculados com L. donovani. A histopatologia mostrou intensa e difusa hiperplasia e hipertrofia do sistema reticuloendotelial com alto parasitismo nos grupos inoculados com L. donovani, enquanto foi encontrado envolvimento focal nestes órgãos nos grupos inoculados 
DUARTE. M. Y. S. LAURENTI, M. D.; ANDRADE Jr., H. F. \& CORBET'T. C. E. P. -- Comparative study of the biological behaviou in hamster of two isolates of Leishmania characterized respectively as L. major-like and L. donovani. Rev. Inst. Med. trop. Sào Paulo, 30 (1): $2127,1988$.

com L. major like, formando nódulos de macrófagos discretamente parasitados.

Ocomportamento biológico seria útil em es tudos preliminares de identificação de cepas de Leishmania em laboratórios regionais e na compreensao da histopatologia das lesoes causadas por diferentes espécimes de leishmanias.

\section{REFERENEES}

1. ADLER. S. - Immunity to protozoa. Oxford. Blackwell Scientific Publication. 1963. p. 235.

2. BRAY, R S. -.. Leishmania, Ann. Rev. Microbiol., 28: 189217.1974

3. BRADLEY.D.J.\& KIRKLEY.J.-Regulation of Leish mania populations within the host. I. The variable course of $\mathbf{L}$. donovani infections in mice. Exp. Immunol., 30 : 119129.1977

4. COUTINHO. E \& COELHO.M. V. -- Leishmaniose tegu mentar experimental. III Patologia comparada da infec cāo de amostras de L. braziliensis, L. mexicana e L. tropica, en animais de laboratorio. Rev. Inst. Med. trop. S. Paulo, 14: 12 29. 1972

5 DUARTE M. I S \& CORBETT. C. E. P. - Histopatho logical and vitra-estructural aspects of interstitial pneu monitis of experimental visceral leishmaniasis. Trans. roy. Soc. trop. Med. Hyg., 78: 683688,1984

6. DUARTE, M. I. S.: SESSO. A. \& BRITO. T. -- Relation ship between glomerular mesangial cell proliferation and amiloid deposition as seen by uitrastructural and morpho metric analysis in experimental Kala azar of the hamster Amer. J. Path., 92: 157.173, 1978.

7. GARDENER.P J -.- Taxonumy of the genus Leishmania A review of nomenclature and classification. Trop. Dis. Bull., 74: 1069 1088. 1977.

8. GELLHORN, A., VAN DYKE, D. B.: PYLES, W. J \& TU PIKOVA. N. A. - Amyloidosis in hamster with leishma niasis. Proc. Soc. exp. Biol. (N. Y.), 61 : 254. 1946

9. GUTIERREZ. Y.: MAKSEN. J. A. \& REINER, N. E. Pathologic changes in murine Leishmaniasis $(L$. donova- ni) with special reference to the dynamics of granuloma formation in the liver. Amer. J. Path., 144: 222 230. 1984

10. HOMMEL, M. - The genus Leishmania. biology of the parasites and clinical aspects. Bull. Inst. Pasteur, 76: 5112.1978

1i. MALEL J \& BEHIN, R _. Leishmaniasis immunity. im munopathology and immunodiagnosis. In: COHEN. S. \& WARREN, K. W., ed. - Immunology of parasitic infections. 2nd. ed. London. Blackwell Scientific Publication. 1982. p. 300355 .

12. MELENEY. H. E.-. The histopathology of Kala azar in the hamster. monkey and man. A mer.J. Path., 1: 147. 1925

13. MOMEN, H.: GRIMALDI Jr., G.: PACHECO, R. S : JAF FE, C. L.: MCMAHON PRATT, D. \& MARZOCHI, M. C A. ... Brazilian Leishmania stocks phenotypically similar to L. major. Amer. J. trop. Med. Hyg., 34: 1076-1084. 1985

14. OTT, K. J. HANSON, W. L. \& STAUBER, L. A. - Course of infection of $\mathbf{L}$. donovani in hamsters inoculated by the intraperitoneal route. J. Parasit., 53: 641 645. 1967

15. PACHECO, R. S. - Caracterizaçáo de cepas e clones de Leishmania pela análise do DNA do cinetoplasto por enzi mas de restriça e por hibridizaça molecular $\mathrm{Rio}$ de $\mathrm{Ja}$ neiro. 1985. (Tese de Mestrado -.. Instituto Oswaldo Cruz (FIOCRUZ)

16. RITTERSON. A. L. - Leishmaniasis in golden hamster J. Parasit. 41: 603-612. 1955

17. SCHNUR L.; ZUCKERMAN. A \& MONTILO. B. - Disse mination of leishmanias to the organs of Syrian Hamsters following intra splenic inoculation of promastigotes. Exp. Parasit., 34: 432-447, 1973

18. SHAW, J.J. - Personal communication. 1985

19. STAUBER. L. A. - Host resistence to the klartoun strain of L. donovani. Rince Institut Pamphect, 45: 80-96, 1958.

20. VAN JOOST, K. S \& SLUTERS, J F. - Appearance of L. donovani (Kenya strain) in the blood of experimentaly infected golden hamsters (Mesocricetus auratus). Trop. geogr. Med., 24: 292 297. 1972.

21. ZUCKERMAN, A \& LAINSON, R -- 3. Leishmania. In KREIER, J.P., ed Parasitic protozoa. London, Academic Press, 1977. v. 1, p. 57-133

Reccbido para publicacào em 31:031987 